\title{
Proletarian Politics Today: On the Perils and Possibilities of Historical Analogy
}

\author{
JAMES FERGUSON \\ Anthropology, Stanford University
}

The analytical terms that make possible the work of social and historical comparison are generally what we might call used goods. We are not the first to handle them, and they come to us with the stains, traces, and taints of their prior uses. Such residues of prior uses create analogical associations, through which prior historical instances or paradigmatic sociological cases can set the terms (quite literally) with which we describe and compare other cases. Sometimes, our analytical terms of comparison invoke such analogies explicitly. When we argue about "apartheid" in Israel, or identify classes of "compradores" and "kulaks" in East Africa, the borrowing of storylines or frames of reference (and not only terms) is undisguised. But even when our terms are more technical or apparently universal, the traces of prior uses cling to them. A political anthropologist today, for instance, cannot describe a "segmentary lineage" society without immediately transporting the educated anthropological reader to the floodplains of Nuerland and the textual world of E. E. Evans-Pritchard. And even less-specialized terms have similarly deep links with well-known and consecrated historical predecessors - can we really discuss "revolution" today without tacitly framing our thinking around the well-worn associations of that word with the paradigmatic or canonical cases that it spontaneously brings to mind? Such analogy-by-association is probably inevitable, and is in any case no obstacle to sound and fruitful comparison. But I will argue that the common bundling-together of analytical terms with conventional or canonical historical analogies is worth more critical and methodological reflection than we have generally given it up to now-both because of the mischief it can do, and (less obviously, but perhaps more interestingly) 
because of the potentially useful creative destabilization that a self-conscious shift to less conventional analogies may enable.

The case I wish to consider involves the terms "proletariat" and "proletarian" in contemporary South Africa. I begin by observing that while these terms are still in use, the historical analogy that was once the explicit justification for that usage-likening the rise of an industrial working class in southern Africa with earlier developments in Europe - is today increasingly under strain. But the conclusion I want to draw from this is not that we should stop using historical analogies, but that we should instead strive to use them in less conventional and more imaginative ways. I therefore do not argue for retiring "proletarian" language on the grounds that it is now out of date, anachronistically out of its proper time and space. Instead, I aim to put the proletarian analogy, and its current problems, in a much more expansive historical context, and thereby to open up a broader set of analogic possibilities. I suggest that expanding the analogy, rather than just scrapping it, may make it possible to give both the term "proletarian" and the analogies it is capable of suggesting new relevance, and new analytic purchase on the present. More generally, I will also suggest that striving to be more self-conscious about the links between the terms of our comparisons and the implicit historical associations with which they are connected may enable us to open up our thinking to a broader range of analogies, thereby displacing the over-familiar paradigmatic cases that currently dominate our analogical imaginations.

Let us therefore begin with the question of, as my title has it, "proletarian politics today." The word "proletarian" is of course forever associated with the work of Karl Marx and particularly with the Marxist tradition of class analysis within which "the proletariat" and "proletarianization" have been central concepts. In most quarters today, such language has a rather antique ring to it. But in South Africa, the concept of "the proletariat" retains both a surprising currency and a measure of real significance. ${ }^{1}$ This is partly as a legacy of the various Marxist orientations that came together in the long years of antiapartheid struggle, partly thanks to its role as a keyword in progressive scholarship and left political theory, and partly as a sort of template for imagining new social classes and new political protagonists (as in the increasingly discussed image of "the precariat"). The result is that a historically very particular, even peculiar category long used to analyze the political economic forms of

\footnotetext{
1 The term is in active use today both in the academic domain and in that of public political discourse. Perhaps the most visible political examples can be found in the "old left" discourse of trade unionists like Irvin Jim, General Secretary of the National Union of Metalworkers of South Africa (NUMSA), who recently called via a Facebook post for a political leadership that might help the "advanced part of the working class" to "steer the whole mass of the proletariat and the semiproletariat on to the correct road."; https: /www.facebook.com/pg/IrvinJimPage/posts/?ref=page_internal (accessed 21 Aug. 2017). For a sophisticated recent example of academic work using an analytical language of proletariat and proletarianization, see Jacobs 2017.
} 
nineteenth-century Europe often appears, in both historical and contemporary accounts of southern Africa, as if it were a simple descriptive term and not, as it seems to me to be, a rather strained and anachronistic allusion.

This state of affairs can only be explained by the fact that, from the earliest days of social scientific analysis of the region, we have labored under the spell of a powerful historical analogy, likening contemporary events in southern Africa to those of Europe in its time of capitalist industrialization. As I have written elsewhere (Ferguson 1999), the mid-twentieth-century anthropology of what was called "social change" worked from the start with the idea that industrializing Europe provided the key to understanding events in the then-expanding mining economies of southern Africa. The social anthropologist, Max Gluckman, for example, founder of the "Manchester School" of anthropology and director of the famed Rhodes-Livingstone Institute, identified the region's fundamental sociological issue as what he called "the African industrial revolution" (Gluckman 1961). For new fieldworkers starting research in the region, Gluckman reportedly assigned, as required reading for the ship passage from Britain, not anything to do with southern Africa, but two then-influential works on the social history of industrializing England in the late eighteenth and early nineteenth centuries (J. L. Hammond and Barbara Hammonds' The Town Labourer [1917], and The Village Labourer [1920]), in the belief that they provided the appropriate framework for understanding the social realities that the researchers would soon encounter. ${ }^{2}$

Historians, too, saw in southern Africa a historical process that in important ways recapitulated earlier developments in Europe, a process characterized by primitive accumulation, the expansion of a capitalist mode of production, rural dispossession, and the creation of an urban proletariat. Neither the anthropologists nor the historians were blind to the particularities of the region or its manifest divergences from European trajectories of capitalist development. Yet there was a powerful sense that, in broad strokes, Africa was now going through something that Europe had already experienced. The Eurocentric frame was in this respect taken for granted.

Moving into the later twentieth century, the story of the emergence of a working class was perhaps the single dominant theme in an extremely impressive (and mostly Marxist) radical scholarship that flourished in the period. But as rich as these discussions often were, what strikes one now, looking back at them, is how little doubt there seemed to be that the term, "proletariat," was a useful and appropriate category for characterizing the urban and semi-urban masses that had grown up around the new mining towns and other urban settlements. This was in marked contrast with scholarship on the countryside, where sharply critical discussions across several disciplines relentlessly

\footnotetext{
2 This is per Michael Burawoy, conveying an account given to him by Jaap van Velsen (personal communication, 22 Aug. 2014).
} 
questioned the relevance and validity of European analogies and terminologies. Is the term "feudalism" really of any application in Africa, asked Jack Goody (1963)? Do European terms like "tribe" not distort scholarly understandings of contemporary and precolonial African polities, wondered Terence Ranger (1985)? "Are African Cultivators to be Called Peasants?" inquired Lloyd Fallers (in the title to an influential 1961 article). But few seemed to doubt (at least in southern Africa) that African industrial laborers were to be called proletarians. As I have argued elsewhere, this was not just a matter of terminology, but of an imagined plot-line that shaped the way that social and political developments were both narrated and understood (Ferguson 1999).

By now, this is all fairly familiar ground. But the new wrinkle I want to introduce into the discussion here is the observation that the term "proletariat" that we in recent decades have used as a kind of historical analogy (likening certain propertyless, mostly urban people to the burgeoning industrial working classes of nineteenth-century Europe) was, in its own time, itself already a historical analogy, one that leapt across not just a century or two of history, but nearly two millennia.

As Marx was well aware (schooled, as he was, in Roman law), the concept of the proletariat had its origins in the administrative practices of ancient Rome, where it appeared as a census category, applying to people who were free citizens but lacked even the minimal ownership of property required for membership in the class-based hierarchy of the Roman Republic. This is a social category of free but propertyless citizens, whose numbers exploded during the imperial period, most of all in the capital city of Rome itself.

In contrast to Marx's own later usage, the Romans who were designated as "proletarian" were not principally wage laborers, a category in fact little developed in the Roman economy. Rather, they seem to have made their presence felt in the wider society less as workers than as what Eric Hobsbawm long ago analyzed as "the city mob" (1965: 108-25). Their social role, that is, was grounded in politics and patronage more than wages, and relied on distributive flows quite as much as productive labor. Marx himself noted this in the preface to the second edition of his celebrated Eighteenth Brumaire of Louis Bonaparte, citing the historian Sisimondi's observation that "the Roman proletariat lived at the expense of society, while modern society lives at the expense of the proletariat" (Marx 1978: 5).

The use of the term "proletariat" to designate a class specifically composed of wage laborers was, as Peter Stallybrass (1990) has shown, a terminological innovation of the nineteenth century, one in which Marx himself played a leading role. Older usages had adhered much more closely to the original Roman sense in suggesting an impoverished, disorderly, and possibly dangerous array of paupers and hangers-on. "Before Marx," Stallybrass has written, "proletarian (prolétaire) was one of the central signifiers of the passive spectacle of poverty"; "[t]he proletariat, in other words, was not the working class: it 
was the poor, the ragpickers, the nomads" (ibid.: 84). On Stallybrass's account, Marx created "the proletariat" as a coherent and morally upright working-class protagonist only through a process of purification, where many of the heterogeneous and unsavory elements of what had been known as the proletariat were extracted, and safely contained within another category: that of the Lumpenproletariat. This figure, as is well known, Marx and Engels treated with undisguised contempt: "the social scum," "that rotting mass" of parasites and criminals, "this scum of depraved elements from all classes" (quoted in Ferguson 2015: 221), "turning upon this category," as Stallybrass observes, "much of the fear and loathing, and the voyeuristic fascination, that the bourgeoisie had turned upon the previously less specific category of the proletariat" (1990: 82).

It is only this "purification" of the older meanings of proletarian (a purification that we have long since forgotten, and today take for granted) that enabled the modern understanding of "the proletariat" as a coherent sociological entity characterized by both specific economic functions (productive wage labor) and specific moral-political characteristics (a "respectable" working class capable both of gaining class consciousness and of pursuing political aims of universal significance). But it is precisely this purification that separates the contemporary Marxist concept of "the proletariat" from the contemporary global urban population to which it today finds such increasingly tenuous application. The purified proletariat concept struggles to find traction here precisely because the surging new urban populations of the global South so often subsist via improvised, "informal," and, one is tempted to say, "lumpen" livelihood strategies that have increasingly displaced stable wage labor as the economic basis of urban livelihoods across much of the world. I would therefore like to return, for a few moments, to the original, Roman reference point of Marx's analogical proletarians. By messing up a bit the "proletariat" that Marx so carefully purified, we may find both better ways of using some familiar metaphors, and better ways of understanding the possibilities and dangers of historical analogy.

THE PROLETARIAN POLITICS OF ANCIENT ROME

Before going any further, it is time to introduce a rather enormous caveat: which is that, perhaps unsurprisingly for a scholar specializing in modern southern Africa, the author does not, in fact, know very much about ancient Rome. If the purpose of this essay were to contribute to scholarly understandings of Roman society or Roman history, this would be highly embarrassing, and indeed, disqualifying. But in fact, this essay has no such purpose. It should be regarded not as a report on knowledge but rather as a kind of conceptual experiment. With that aim in mind, I hope that, once the results of this experiment emerge, a generous reader will forgive the obvious lack of expertise, as well as what will surely appear to any real specialists as, at best, oversimplifications. For let there be no misunderstanding: this paper is in no way a 
contribution to the historiography of Rome. Its aim is to do no more than summarize very crudely some basic facts culled from the secondary literature about the social order of ancient Rome (and especially the city of Rome in its imperial period) in order to launch a provocation regarding our use of historical analogies. If it has any contribution to make, it lies in that provocation, and certainly not in any original knowledge or insight about Rome.

As far as I can tell from that secondary literature, ${ }^{3}$ the diverse collection of Roman citizens picked out by the old census category "proletarian" was in fact less like Marx's respectable, wage-laboring "proletariat" than it was like the "impurities" that he systematically removed from it. It looked, that is, quite a bit like Marx's much-disparaged Lumpenproletariat. Consider the following account from the late imperial period: "The idle and lazy proletariat ... devote their whole life to drink, gambling, brothels, shows, and pleasure in general. Their temple, dwelling, meeting-place, in fact the centre of all their hopes and dreams, is the Circus Maximus.... Most of these people are addicted to gluttony. Attracted by the smell of cooking and the shrill voices of the women ... they stand about the courts on tip-toe, biting their fingers and waiting for the dishes to cool (Ammianus Marcellinus [ca. 330-395], quoted in Grant 1992: 81)."

This is an elite account, of course, but it and others like it present us with precisely that "passive spectacle of poverty" that Marx had expelled from his picture of the proletariat as a respectable working class. And if these Roman "proletarians" sound less like industrious 9-to-5ers and more like an unemployed underclass, this should not be surprising. As I have noted, the original definition of the Roman proletariat identified a kind of intersection of free citizen status and propertylessness. That is, it was a status not defined by labor at all, but by a lack of property, on the one hand, and a kind of political membership, on the other. I will suggest shortly that this shift from labor to things like citizenship and property is quite useful when it comes to the analogical possibilities of the term in today's context.

Those who lacked significant property are poorly documented in the written texts and inscriptions that provide the basis for most of what we know about the social structure of ancient Rome; they are what Knapp (2011) has termed the "invisible Romans." But available sources seem to suggest that the key social power of Rome's propertyless (but non-slave)

\footnotetext{
3 In my very limited sampling of this literature, I found the following works to be most helpful. For an accessible overview of the social and political order: Beard 2015; on the social structure, social categories, and socioeconomic practices that composed that order: MacMullen 1974; on the socio-economic position of poor but free Romans in particular: Morely 2006; and Knapp 2011; on practices of giving and patronage, and relations between wealthy benefactors (including the Emperor) and their recipients, Veyne 1990; and Brown 2012 (especially Part I). The most useful of several collections of translated primary sources that I reviewed was Parkin and Pomeroy 2007. Bairoch (1988) helpfully situates the Roman case in a global overview of urban economic history.
} 
urban citizens did not lie principally in their capacity to labor, but in other capacities that more closely resemble those of Hobsbawm's "city mob," especially the capacities to both offer a following and instill fear. One key sort of power involved the ability to augment (through reproduction) the population for purposes such as colonization or, in the later imperial period, staffing the army. As the name proletarius, "the one who produces offspring," suggests, the ability to produce children was among the few assets these propertyless citizens were acknowledged to possess. But in other domains, too, being able to provide demographic bulk mattered, whether in the form of political followers for politicians, retinues and admirers for notables, or clients for various sorts of patronage. As Paul Veyne (1990) famously argued, Roman elites needed to have their glory reflected in a pool of admirers; leaders needed followers; and the great man needed not just money and power but, more fundamentally, to be celebrated, to be appreciated, to be praised - indeed, to be loved. This was one of the social tasks performed by the Roman proletariat.

In economic terms, it is important to note the prevalence of what we might, in anachronistically modern terms, call mass unemployment among the free but propertyless citizens of ancient Rome. The widespread practice of slavery of course reduced the need to hire labor, so there simply was no regular market for long-term workers (Parkin and Pomeroy 2007: 215). In fact, where paid labor existed beyond short-term casual arrangements, it was generally subsumed within clientelistic social relations that blurred the lines between wages and the gifts and generosity of a patron. And few could count on such arrangements. Again, the historical evidence on poor livelihoods in Rome is quite sparse, but according to one author (Bairoch 1988: 83), the unand underemployed "must certainly have exceeded 30 percent, if not 40 percent, of the population of working age." Knapp has more recently put it even more strongly, concluding that "most people were not regularly employed" and "lived on the edge much if not all of the time" (2011: 98, my emphasis). And these "un- and under-employed" seem to have suffered from extremely precarious - indeed, "lumpen"-like - conditions of existence. One source speaks of "the large class of poor free workers who had no steady income and probably lived a marginal existence" (Shelton 1988: 133), while another states, "Rome remained notable into late antiquity for the presence of a population living 'informally in the crevices of the towering buildings, sleeping rough in tabernae or huddled in the vaults between the seating of theatres, circuses and amphitheatres" (Atkins and Osborne 2006: 9, quoting Ammianus Marcellinus). Knapp notes that beggars "abounded," while casual day laborers were likely not much better off, living as they did in a "highly conditional" state with an "always uncertain" future (2011: 100, 98).

Most who were employed were what we might today call "selfemployed," and the city contained innumerable craftsmen, artisans, and petty traders crowded into shacks and stalls around the city. But as MacMullen 
(1974: 89) has observed, "the very populousness of crafts associations" must be interpreted alongside "evidence for the subdividing of money-making opportunities"; one must appreciate "how atomized industries were, how minutely subdivided into little shops and little agencies" (ibid.: 98-99) that normally yielded only tiny slivers of livelihood. Rather than a modern bourgeoisie or commercial sector, they must have resembled something closer to what we would today call "the informal economy"; contemporary writers, certainly, did not hesitate to lump them among "the poor" and the riff-raff. As was the case for the laborers, relations with powerful patrons were valuable, if not essential, and craftsmen were ever-attuned to the possibility of attaching themselves as clients to rich and propertied benefactors or protectors. As one author of the time put it, the poor were those who "looked always to the fingers of the rich" (cited in Brown 2012: 56).

If those who were classified as proletarians (that is, the poorest of the plebs, free Roman citizens lacking almost all property) were dependent on relations of patronage with their social superiors, they were often even more dependent on their relation with the state, a relation often personalized as a relation with the Emperor himself. A key element of this dependence took the form of direct distribution from the state that was based on citizenship, not labor. Via the well-known "corn laws," food was distributed directly to the urban citizenry by the Emperor, who was also expected to provide lavish popular entertainments - thus the famous phrase, "bread and circus."

But what is not always appreciated about these arrangements is their sheer scale. At its height, the Roman metropolis was a city with a population of perhaps a million or more, a number that approaches the size of the largest European cities even as late as the early industrialization period of the nineteenth century (Bairoch 1988: 82; Beard 2015: 21). And a huge proportion of this population received organized, direct distribution of grain from the state. ${ }^{4}$ The numbers shifted over time, and estimates in any case vary, but it seems that some three hundred thousand or more residents of the capital were receiving free allocations in the time of Augustus (Parkin and Pomeroy 2007: 49) and much higher numbers have been cited for later periods (Bairoch 1988: 82-83; but cf. Veyne 1990). Even larger numbers benefited from the controlled price of the grain that was distributed by the state, the price being heavily subsidized in times of scarcity (Veyne 1990: 236-40). In addition to this, substantial numbers of poor citizens in the Roman capital, and indeed all of Italy, were granted family allowances-cash payments

\footnotetext{
4 Knapp (2011: 101) points out that the city of Rome was in some ways unique (an "aberration”), and reasonably warns against extending the picture of a dole-dependent populace that emerges from the imperial capital to the Empire as a whole. My interest here, though, is precisely in the modes of distribution that appeared in their most developed form in Rome itself, and I make no claims that they are representative of the wider Empire.
} 
awarded to families with children. ${ }^{5}$ All of this enabled the subsistence of free but propertyless citizens who would likely have struggled to survive via productive labor alone: "broad masses of parasitic recipients of grain," as one author has pejoratively put it, who "always constituted a Lumpenproletariat" (Alfoldy 1985: 136).

As Paul Veyne (1990) has emphasized, grain was distributed not to the poor (in contemporary terms, we might say there was no "means testing"), but to the people (see also Brown 2012: 68-71). It was understood as a kind of ostentatious gift, a grand gesture bringing glory to the giver, but also as a kind of obligation of honor, since to allow the people of the great imperial capital to go hungry would be both shameful and, in the event of food riots, dangerous. The Emperor's provisioning of the Roman people, then, Veyne insisted, must be situated within the broader ancient culture of public giving and public glory that he termed "euergetism."

But it is worth emphasizing that, even as such gifts emphasized and enacted the vast social gap between rich and poor, notions of fair shares were not absent, either. Veyne points out that the first creation of the corn law occurred when anger stemming from food shortages became linked to a complaint about the "unequal distribution of dividends," in which "those who shed their blood to enlarge the Empire were not receiving their fair share of the conquest" (1990: 241). Veyne suggests this was less the expression of an abstract and universal principle than a political ideology born of a specific conjuncture, one which enabled an "allegory of justice in which the body politic was likened to a share-issuing company, in order to make more concrete the idea that everyone had a right to a livelihood" (1990: 241-42). More recently, Neville Morely has argued both for what he calls the "practical significance" of food security as a political gain resulting from "pressure from below" and the "ideological significance" of the concession "that all Roman citizens should have the right to demand a share of the spoils of empire" (2006: 39).

There is much that could be said about all of this. For my purposes here I want to emphasize only that livelihoods here came to the proletarian poor, to some considerable extent, not only via economic exchanges of labor, but also as a reward for political allegiance, as a demonstration of the power and generosity of the sovereign toward those who must adore him, or as a response to an actual or potential threat to public order.

Let me also state here what I have up to now left implicit: there are surprising points of similarity between the Roman case described here and contemporary southern Africa, and especially South Africa, where high levels of urbanization coexist with both massive structural unemployment and extensive state programs of direct distribution to citizens.

\footnotetext{
5 Veyne 1990: 367-77. The term "family allowances" is Veyne's (ibid.: 367); the Romans spoke of the Alimenta.
} 
To pursue this parallel, let us observe that neither the economic nor the political life of the Roman capital can be understood without situating it within the vast streams of resources that flowed into Rome, but were produced elsewhere. "Rome," as Bairoch has put it, was a distributive hub-it "received much and furnished little" (1988: 83).

A long tradition of social evolutionist typologies of cities puts such "political" or "administrative" city types firmly in the past, and discourages any hope of finding in such cities substantial or meaningful parallels with modern metropolises. Giddeon Sjoberg's classic account (1965) sharply distinguished what he called "pre-industrial cities" from industrial ones. Pre-industrial cities (understood as "ancient" or "traditional"), in this view, were nonproductive, and extracted value from the countryside; modern cities, in contrast, were industrial and productive. Henri Lefebvre (2003) likewise traced an evolutionary progression leading from what he called the political city to the mercantile city to the industrial city. But there is no reason to grant such historical sequences any sort of universal truth or necessity. If one looks at the history of urbanism in, say, Zambia, the sequence is neatly inverted: first came the industrial city, in the form of the mining towns of the Copperbelt; later, what had started as minor administrative centers and trading posts, such as Lusaka and Ndola, become real cities; then, finally, the expansion of state employment and tertiary sectors made them into distributive hubs and what Lefebvre would call "political cities." In fact, in many parts of the continent, cities have steadily become less industrial, not more, and increasingly "political" or "distributive" in character-reminding us, in this respect, of Rome, while suggesting that the "parasitic" character that Sjoberg (1965) attributed to "the preindustrial city" may not in fact be the relic of the past that he implied. One might also recall here Max Weber's observations about the importance, in both the ancient and the modern world, of what he called "consumer cities," whose economies were supported by the purchasing power of those with (in his incisive terms) "politically determined incomes." These "political incomes," in his account, could include "officials who spend their legal and illegal income in the city" as well as other "political power holders" and even pension-recipients (Weber 1969: 26-27).

Other details of ancient Roman society suggest further parallels. The ancient Roman capital was plagued by structural unemployment, and I have already cited an estimate of 30-40 percent unemployment that would be quite at home in current discussions of South African cities. The prevalence of precarious and short-term labor arrangements, which I have noted was characteristic of Rome, is also increasingly to be observed in South Africa. If stable, long-term wage labor was undermined in Rome by the availability of slaves, one might consider the extent to which a similar undermining has occurred in South Africa via machines, which in recent decades have displaced hundreds 
of thousands of formerly secure wage laborers in industries such as mining and agriculture.

In Rome, material support from the state supported a huge chunk of the population. This conspicuously took the form of direct distribution to citizens, where resources were transferred not in exchange for labor, but as a perquisite of citizenship, ${ }^{6}$ and as a gift rulers hoped would gain them clients and political supporters, while keeping at bay the potential unrest or violence of urban masses. This, too, would sound familiar in South Africa, where some 30 percent of all citizens receive social payments directly from a state seeking political adherents (in the form of voters), under the shadow of palpable and ubiquitous elite fears of urban insurrection on the part of propertyless citizens. Indeed, in South Africa, as in Rome, even very poor citizens retain certain social powers, among which are, as I earlier said of Rome, "the capacity to offer a following, on the one hand, and to instill fear, on the other." It is also noteworthy that, while state payments to the poor in South Africa include old age pensions and disability grants, there is also, as in Rome, a special grant paid to households with children (the Child Care Grant, paid to the caregiver of any child under the age of eighteen [in Rome it was sixteen $\left.{ }^{7}\right]$ ). As Weber pointed out, "political incomes" may come in many kinds. Direct state transfers to citizens were crucial forms of political income in ancient Rome, just as they are today in South Africa. And in both cases, relations of clientelism and dependence have been crucial to sustaining the livelihoods of the propertyless, in a social structure of extreme inequality. In South Africa, much as Peter Brown (2012: 56) has said of ancient Rome, "we are dealing with a steeply hierarchical society, held together by innumerable chains of dependence." On all these points, the analogy to antiquity seems weirdly relevant to our southern African present, in some ways more so than the much more recent (but increasingly unhelpful) analogy with nineteenth-century Europe.

NON-CAPITALIST ANALOGIES FOR A CAPITALIST SOCIETY?

We cannot really think without analogies, since we always apprehend the new and unfamiliar in term of things we know about earlier happenings and prior or already-familiar cases. Historical analogy, used in a self-conscious and disciplined way, has its uses as well as its pleasures. But it also imposes limits and creates blind spots. Juxtaposing the historical analogy we are most used to (the proletariat as emergent class of industrial wage laborers) with another, less familiar one (the proletariat as propertyless citizenry, dependent on

\footnotetext{
${ }^{6}$ As Brown has emphasized, citizens were a privileged group, and received their allotments of grain with considerable pride. To receive a dole of food, he notes, "did not make one a beggar. It made one a citizen" (2012: 69-70).

7 That is the estimate of Veyne (1990: 371).
} 
clientelistic distribution and direct state grants), may help bring some of those limits and blind spots into better focus.

In this spirit, I have here offered the suggestion that a number of features of the economic and social situation of the urban poor in contemporary South Africa surprisingly seem to call to mind the proletariat of ancient Rome as much as they do the proletariat of nineteenth-century industrializing Europe. But I should note that the unexpected conceptual relevance of ancient categories for thinking about contemporary developments is not just a matter of southern Africa. Nor am I the first to take note of it.

A number of theorists have recently applied historical analogies to contemporary realities in ways that, whatever one might think of the merits of their specific arguments, make a hash of the old idea of a progressive movement through linear time - as if we are all now (like Kurt Vonnegut's character, Billy Pilgrim, in Slaughterhouse Five) "unstuck in time," jumping in disorderly and decontextualized fashion from one point in time to another far distant from it. Thus, while we used to feel sure of an orderly progression, at once historical and theoretical, in which Hegel leads to Marx as the past leads to the present, Žižek has recently suggested that it is Marx's conception of the proletariat that has a decreasing purchase on contemporary realities, while Hegel's idea of "the rabble" more and more really speaks to present conditions. Indeed, he suggests, "one can argue that the position of the "universal rabble' perfectly captures the plight of today's new proletarians." Rather than being exploited as wage laborers, "today's rabble is denied even the right to be exploited through work [...]; and exactly as described by Hegel, they sometimes formulate their demand as the demand for subsistence without work...." (Žižek 2012: 440). Turning to Rome, Hardt and Negri's influential figuration of the emergent form of contemporary global capitalism as "Empire," of course, referred not to any Marxist principle, but explicitly to "the [ancient] Roman tradition of imperial right" as its foundation (2000: 10). More recently, Göran Therborn, the grand old man of sociological theories of class, wrote a prospectus on the future of class in the twenty-first century, concluding that the "working class" that had been the dominant political force of the twentieth century is rapidly receding in importance, and that "the time when [it] was seen as the future of social development ... is unlikely to return" (2012). Instead, he points to the ascent of middle-classes organized around consumption, and to what he calls "popular classes" that he terms, with little elaboration, "plebeian." Another sociologist, meanwhile, Carlos Forment, has developed a concept of what he calls "plebeian citizenship" to interpret contemporary vernacular politics in Buenos Aires (2015). The subaltern social categories of former eras, and particularly those of ancient Rome, thus seem to have a strange sort of currency just now. But I take the theoretical provocation here to go beyond the literal question of whether the social categories of bygone eras are really applicable to the present, and instead to suggest the value of a certain sort of principled 
anachronism in shocking us loose from the nineteenth- and twentieth-century categories of thought that still so largely captivate our theoretical imaginations.

Still, it may be hard to quiet the worry that there is something fundamentally mistaken about this turn to the ancient world since (whatever the historical differences that might make one hesitate today to liken contemporary southern Africa to turn-of-the-nineteenth-century England as crudely as Max Gluckman once did), it remains the case that industrializing Europe was a capitalist system, and ancient Rome, whatever else one might say about it, was not. Shall we, then, simply discard analogies with non-capitalist cases simply because we already know, a priori, that they cannot "really" apply? That, I think, would be to grant far too much power to the operation of naming, as if simply designating a social formation as "capitalist" is already to answer all the key analytical questions about how it works. Instead, I would like to use the surprising resonances of that other, ancient form of proletarian politics to suggest that there is in fact much more going on in southern Africa today than just the development or the unfolding of a capitalist mode of production.

The idea that there was more going on in the region than just the development of capitalism was, of course, a key insight of the old "modes of production" literature, rooted in the theoretical assertion, central to the "structural Marxism" of the 1970s, that there is always more happening in any actual social formation than is present in a structural model of a single mode of production. But even the most subtle of the "modes of production" thinkers assumed that the non-capitalist elements contained in these complex articulations were old and receding, and the capitalist elements new and expanding. In the same way, Eric Hobsbawm (as I noted) wrote insightfully about "lumpen" masses as a key dynamic in modern urban politics. But here again, a meta-narrative of proletarian emergence enabled the confident assigning of some social elements to an archaic past, while others pointed toward an inevitable future. The Hobsbawm text I referenced earlier, let us recall, was titled "Primitive Rebels," and aimed to explicate, as the subtitle put it, "Archaic Forms of Social Movement." In this view, politics based on urban "mobs," or relations of patronage, or direct distributive claims constituted primitive, evolutionarily "early" forms of political resistance, to be eventually replaced by fully modern rebels, modern forms of subaltern resistance, and ultimately, by the mobilization of the organized and "conscious" working class.

In place of these well-rehearsed "expectations of modernity" (as I once called them [Ferguson 1999]), the current situation suggests a need to learn to contemplate futures less well known and less confidently anticipated, and to consider the possibility that certain non-capitalist elements that older habits of mind would consign to the past may in fact be new and emergent, not old and residual. Where once we talked confidently of proletarianization, today it seems that increasing numbers of people, in a range of countries around the globe, are supported by neither agriculture nor wage labor. In 
many of these countries, as in ancient Rome, direct state distribution forms a central part of the material livelihoods of these social classes (in the form of cash transfers and other social payments, as I have analyzed elsewhere [Ferguson 2015]). And, as in Rome, we encounter urban forms that are driven not by industrialization but by the pursuit of distributive possibilities - not booming mining towns whose vitality derives from production and industry, but "administrative" and "political" cities like Lusaka, or Luanda, where the city appears as the site less of production than of distribution and consumption.

As J. K. Gibson-Graham (1996) pointed out (in a text that I keep coming back to, and that is now more than twenty years old), contemporary societies, whether in the global North or South, are never simply "capitalist" through and through. Non-capitalist ways of living and producing are all around us, and they are not in the process of vanishing. Indeed, if our measure of the extent to which a social formation should be understood as capitalist is the predominance of wage labor (a measure that I suspect Marx would approve), then we must conclude that non-capitalist elements are, at least in some parts of the world today, in ascendance, not decline.

Now let me be clear: "non-capitalist" here is not the same as "good." Slavery, after all, is non-capitalist, and neither Rome's outrageously hierarchical social structure nor its imperial militarism should invite emulation. But this is no time to cede the future to capitalism either. At a time when fewer and fewer of our fellow global citizens are able to be either capitalists or wage laborers, and when more and more are adapting to what Michael Denning (2010) has termed "wageless life" by pioneering other ways of getting by, we need new ways of understanding how a politics of the propertyless might proceed.

What are the real challenges and opportunities for proletarian politics today in the southern African region, if by "proletarian politics" we understand not a politics of the wage-earner, but a politics by and for those without property? The nineteenth-century European analogy suggests that this awaits the continuing development and consolidation of a "real" working class, which can then proceed to organize, withhold its labor, organize class-based political organs, and so forth. Such an analogy would also suggest that economic distributions unconnected to labor, and political forms such as clientelism and paternalism, belong to the past - the prehistory of capitalism, not its present, and still less its future. The Roman analogy, in contrast, suggests other clues that point to other understandings. Here I summarize some of the possibilities of that analogy by listing five themes that emerge from my understanding of the Roman material. For each, I point to a contemporary topic of relevance to southern Africa - and perhaps even to the global South more broadly - that a view from Rome might illuminate.

(1) The importance of direct state distribution as both livelihood source and political tactic. Here, the contemporary reality I have in mind is the 
recent massive expansion, across the global South, of programs of cash transfer payments from states to their poorest citizens. As I have noted elsewhere (Ferguson 2015), these programs do not simply represent belated attempts to reproduce the welfare systems of the North, but operate with quite different assumptions and rationalities. Where northern welfare states grew up around the rise of industrial working classes, and specifically aimed to provide a kind of insurance for "families" understood to be made up of "workers" and their "dependents," the new programs of cash transfer that have swept across the global South have no place for the figure of "the worker." Instead, they target beneficiaries based on criteria that are independent of labor, including criteria that would have been familiar to the proletarians of ancient Rome, namely citizenship, age, and number of children. While the nineteenth-century script of "proletarianization" struggles to understand modern distributive politics of this kind, the Roman analogy points to a different way of understanding how both livelihoods and modes of distribution might be organized in ways that have little to do with wage labor.

(2) The centrality of clientelistic vertical alliances of the poor with wealthy patrons or benefactors, and the relative weakness of horizontal organizations based in labor and the threat to withhold it. Here, I refer to the continuing significance of the issue of dependence, both in systems of social assistance and the sociology of wageless communities, in southern Africa and beyond. It is not as if such issues have been neglected by social scientists (that is hardly the case), but stubborn assumptions continue to construe such alliances as either pathological (the dreaded "dependency" of social policy discourse) or backward (traditional and pre-modern "clientelism" and "patrimonialism" that regrettably poison the properly modern forms of politics, whether understood in terms of class consciousness and class interest, or of rights-based democratic liberalism and "civil society"). Here, attending to a more complex and historically deep genealogy of proletarian politics might help to bring our attention to, and thereby inhibit, the smuggling in of these modernist plot-lines from the nineteenth and twentieth centuries.

(3) The importance of political and social obligations on the part of the propertied, rooted in what Veyne called euergetism (or the obligation to give), and the related sense that, as he put it, wealth is "a trust, a possession in which the community at large has a share" (Veyne 1990: 10). Here I point to the increasing role played in so much of the world by non-profit, donor-driven NGOs and philanthropic organizations. These institutions are increasingly powerful players on the political and social scene across vast parts of the world, but they have motives and modes of operation that are very different from capitalist firms. Indeed, their programs are hard to understand in terms of the imperatives of a capitalist production system, and they typically engage their "target populations" neither as workers nor as customers, but as "beneficiaries." But if a figure of today's global economy like Bill Gates 
does not fit Marx's image of a capitalist very well, perhaps we might make some progress by trying out Paul Veyne's idea of the "notable." The Romans, certainly, understood that the ceaseless quest of the wealthy and the powerful for renown, recognition, and praise was not outside of politics, but at its very heart.

(4) The idea that direct distribution may be justified by reference to the premise that the citizens of a great polity, independently of their role in the system of production, have a claim to a share of the wealth flowing into it. Here I have in mind the very similar ideas currently circulating in southern Africa around the proposition that poor citizens should be able to claim certain rights of ownership over the mineral wealth produced by "their" countries - a claim to what I have elsewhere called "a rightful share" (Ferguson 2015). Progressive political mobilization in the North has long been based on the claims of labor, and on the assertion that the value of the wealth that a society produces properly belongs, at least in some substantial measure, to those who did the hard work of producing it. But where large parts of the population are durably excluded from the chance to engage in such productive labor, many claims to a share of society's goods and services must be advanced through other sorts of arguments. And here, the old Roman idea that even the owners of nothing (the propertyless proletarians) are nonetheless - as citizens - owed something does not sound archaic at all, but rather quite up to date.

(5) Finally, we might note the wide contemporary applicability of that form of Roman proletarian agency that was rooted both in urban presence and in the fear that such presence may provoke. Here, it is possible to identify links to contemporary attempts to go beyond the limitations of the construct of citizenship as the basis of political and economic rights, and the possibilities of an expanded concept of "presence" as enabling new sorts of political identities and political claims (an idea I have briefly explored elsewhere [see Ferguson 2015, Conclusion]). At its simplest, such a power of presence involves a power not to withdraw labor but to inhabit, and sometimes to disrupt, social space. In the great mega-cities of the global South, for instance, basic foodstuffs have long been subsidized by the state for populations who, it is feared, might otherwise engage in food riots or other criminality. More broadly, in the politics of such urban environments, specific demands for service provision and practical everyday needs of residents (whom Partha Chatterjee has termed "denizens" rather than "citizens") are often more forceful than the legalistic rights claims of "civil society" or the orderly economic demands of trade unions (Chatterjee 2006). In understanding such a "politics of the governed" (in Chatterjee's phrase), the Roman analogy might help us to get beyond the nostalgic quest for a unitary class subject defined by labor (implicitly modeled on Marx's nineteenth-century proletariat), and to recall instead the very different way that the original (Roman) proletariat made its presence felt-not principally via 
either labor or political representation, but through physical presence and the implicit fear it was capable of evoking.

These hints, arrived at by refracting contemporary realities through the unlikely prism of ancient Rome, supplement rather than replace those suggested by other, more conventional, historical analogies. But they are of no small relevance to the actual condition of the southern African proletariat, and they may also perhaps help us to understand and appreciate forms of politics elsewhere that appear as invisible or even contemptible under the lens of more familiar analogies. As I have argued at some length elsewhere (Ferguson 2015), as the ability for many to make claims rooted in labor is declining, new sorts of bases for claiming material support and social recognition are emerging. These include political grounds of citizenship and belonging as well as quasi-familial and cosmological obligations of rightness and honor that would have been very familiar to the ancient Romans, together with claims of social equality and the rights of the poor that would have been totally alien to them.

\section{CONCLUSION}

A historical analogy, like any good metaphorical device, can take us to some interesting places. But as Ulf Hannerz once remarked, "Whenever one takes an intellectual ride on a metaphor, it is essential that one knows where to get off' (1992: 264). Users of the historical analogies discussed in this paper, I have observed, have sometimes had to be told where to get off. Those who likened mid-twentieth-century mineworkers in Zambia to British coal miners two centuries earlier were not, as they sometimes imagined, observing a substantive identity of natural kind (like, say, identifying two rocks as both composed of quartz) - they were applying a complex historical analogy. That analogy in certain ways illuminated matters quite helpfully. Taken too literally, however, the same analogy had a powerful potential to mislead and confuse.

The same may be true of other figurations of the proletarian that are more obviously and self-consciously analogical in intent, such as my invocation here of the Roman proletariat. Certainly, we should not suppose that rediscovering the "original" meaning of the term "proletarian" will somehow tell us what today's popular urban classes "really are," still less solve all the contemporary analytical problems posed by "working classes" that are so often not in fact working. But if we can keep focused on the twinned dangers and possibilities of historical analogy - if we can, that is, both think analogically and remember to tell ourselves, from time to time, where to get off-we may find that there is something to be gained from seeking our analogies elsewhere than those canonical places and times that we have become so accustomed to taking as our points of historical and sociological comparison. Indeed, it may be that only by expanding the range of our comparative and imaginative points of reference will we be able to find our way to a more adequate understanding of proletarian 
politics today, as it really exists and not as we might wishfully or nostalgically imagine it.

\section{REFERENCES}

Alfoldy, Geza. 1985. The Social History of Rome. London: Croon Helm.

Atkins, Margaret and Robin Osborne, eds. 2006. Poverty in the Roman World. New York: Cambridge University Press.

Bairoch, Paul. 1988. Cities and Economic Development: From the Dawn of History to the Present. Chicago: University of Chicago Press.

Beard, Mary. 2015. SPQR: A History of Ancient Rome. New York: Liveright Publishing.

Brown, Peter. 2012. Through the Eye of the Needle: Wealth, the Fall of Rome, and the Making of Christianity in the West, 350-550 AD. Princeton: Princeton University Press.

Chatterjee, Partha. 2006. The Politics of the Governed: Reflections on Popular Politics in Most of the World. New York: Columbia University Press.

Denning, Michael. 2010. Wageless Life. New Left Review 66: 79-97.

Fallers, L. A., 1961. Are African Cultivators to Be Called "Peasants"? Current Anthropology 2, 2: 108-10.

Ferguson, James. 1999. Expectations of Modernity: Myths and Meanings of Urban Life on the Zambian Copperbelt. Berkeley: University of California Press.

Ferguson, James. 2015. Give a Man a Fish: Reflections on the New Politics of Distribution. Durham, North Carolina: Duke University Press.

Forment, Carlos A. 2015. Emergent Forms of Plebeian Citizenship: Everyday Ethical Practices in Buenos Aires's La Salada's Market. Current Anthropology 56 (supp. 11): S115-S125.

Gibson-Graham, J. K. 1996. The End of Capitalism (As We Knew It): A Feminist Critique of Political Economy. Oxford: Blackwell.

Gluckman, Max. 1961. Anthropological Problems Arising from the African Industrial Revolution. In A. Southall, ed., Social Change in Modern Africa. London: Oxford University Press.

Goody, Jack. 1963. Feudalism in Africa? Journal of African History 4, 1: 1-18.

Grant, Michael. 1992. A Social History of Greece and Rome. New York: Charles Scribner's Sons.

Hammond, John Lawrence and Barbara Bradby Hammond. 1917. The Town Labourer, 1760-1832: The New Civilization. London: Longmans, Green.

Hammond, John Lawrence and Barbara Bradby Hammond. 1920. The Village Labourer, 1760-1832: A Study in the Government of England before the Reform Bill. London: Longmans, Green.

Hannerz, Ulf. 1992. Cultural Complexity: Studies in the Social Organization of Meaning. New York: Columbia University Press.

Hardt, Michael and Antonio Negri. 2000. Empire. Cambridge: Harvard University Press.

Hobsbawm, Eric. 1965. Primitive Rebels: Studies in Archaic Forms of Social Movement in the 19th and 20th Centuries. New York: W. W. Norton.

Jacobs, Ricardo. 2017. An Urban Proletariat with Peasant Characteristics: Land Occupations and Livestock Raising in South Africa. Journal of Peasant Studies. DOI: 10.1080/03066150.2017.1312354.

Knapp, Robert. 2011. Invisible Romans. Cambridge: Harvard University Press.

Lefebvre, Henri. 2003. The Urban Revolution. Minneapolis: University of Minnesota Press. 
MacMullen, Ramsay. 1974. Roman Social Relations, 50 B.C. to A.D. 284. New Haven: Yale University Press.

Marx, Karl. 1978. The Eighteenth Brumaire of Louis Bonaparte. Peking: Foreign Languages Press.

Morley, Neville. 2006. The Poor in the City of Rome. In Margaret Atkins and Robin Osborne, eds. Poverty in the Roman World. New York: Cambridge University Press, 21-39.

Parkin, Tim G. and Arthur J. Pomeroy. 2007. Roman Social History: A Sourcebook. New York: Routledge.

Ranger, T. O. 1985. The Invention of Tribalism in Zimbabwe. Gweru, Zimbabwe: Mambo Press.

Shelton, Jo-Ann. 1988. As the Romans Did: A Source Book in Roman Social History. New York: Oxford University Press.

Sjoberg, Gideon. 1965. The Preindustrial City: Past and Present. New York: Free Press.

Stallybrass, Peter. 1990. Marx and Heterogeneity: Thinking the Lumpenproletariat. Representations 31: 69-95.

Therborn, Göran. 2012. Class in the 21st Century. New Left Review 78: 5-29.

Veyne, Paul. 1990. Bread and Circuses: Historical Sociology and Political Pluralism. New York: Viking.

Weber, Max. 1969. The Nature of the City. In Richard Sennett, ed., Classic Essays on the Culture of Cities. Englewood Cliffs, N.J.: Prentice Hall, 23-46.

Žižek, Slavoj. 2012. Less than Nothing: Hegel and the Shadow of Dialectical Materialism. New York: Verso.

\begin{abstract}
When contemporary dispossessed urban classes are figured as a "proletariat," a potent historical analogy is activated in which the well-documented experience of the burgeoning industrial working classes of nineteenth-century Europe provides an implicit template for interpreting events and processes far removed in time and space. Yet Karl Marx's own deployment of the figure of the proletariat, which often provides the inspiration and model for such analogic moves, was itself in its own time already a complex historical analogy, invoking the social hierarchies of ancient Rome. Rethinking this doubly analogical intellectual history provides an occasion both for considering the uses and abuses of historical analogy, and for using a reflection on the original (Roman) proletarians as a conceptual lever for prying apart some outdated assumptions about the contemporary politics of certain propertyless urban populations, in southern Africa and beyond.
\end{abstract}

Key words: historical analogy, comparison, labor, proletariat, property, dependence; southern Africa, South Africa, ancient Rome 